\title{
Role of serum leptin in prediction of pregnancy outcome in women with early pregnancy loss
}

\author{
Sheela Maddeshiya, Shakti Jain, Shalini Singh \\ Corresponding author: Dr. Sheela Maddeshiya, Senior Resident, Department of Obs and Gynae, \\ MLN Medical College, Prayagraj, Uttar Pradesh, India; Email : maddeshiyasheela@gmail.com
}

Distributed under Attribution-Non Commercial - Share Alike 4.0 International (CC BY-NC-SA 4.0)

\begin{abstract}
Background: Early pregnancy loss occurs in both natural and in-vitro fertilization mediated pregnancies. Clinical miscarriages occur in $8 \%$ of pregnancies. Most clinically apparent miscarriages occur during the first trimester and aetiology is often unknown. Aim: To determine and compare the level of serum leptin in cases of unexplained early pregnancy loss and previous normal pregnancies and to observe the association between level of serum leptin and pregnancy outcome. Methodology: This case control study was carried out on total of 77 pregnant women in first trimester attending outpatient department and indoor cases in Swaroop Rani Nehru hospital and Kamla Nehru Memorial hospital, Prayagraj over a period of twelve months from September 2018 to August 2019. Patients were divided in two groups: Group I $(n=52)$ included women with history of previous abortion and group II ( $\mathrm{n}=25)$ included women with history of no previous abortions. Serum level of leptin hormone was measured using enzyme linked immunosorbent assay (ELISA) technique. Result: In this study the mean serum leptin level was 19.554 \pm 7.50 $\mathrm{ng} / \mathrm{ml}$ in 1 st sample at $5-8$ week and $27.33 \pm 9.705 \mathrm{ng} / \mathrm{ml}$ in 2 nd sample at 9-12 week in cases with history of previous early pregnancy loss which was higher as compared to control $(12.75 \pm 2.147 \mathrm{ng} / \mathrm{ml}$ and $17.62 \pm 6.53 \mathrm{ng} / \mathrm{ml}$ respectively) which was statically significant $(\mathrm{p}<0.0001)$. The mean serum leptin levels in pregnant women who aborted during study was higher $(21.652 \pm 7.716 \mathrm{ng} / \mathrm{ml}$ at $5-8$ weeks and $31.472 \pm 8.56 \mathrm{ng} / \mathrm{ml}$ at $9-12$ weeks) than the women who had successful continuation of pregnancy $(\mathrm{p}<0.0001)$. Conclusion: Hyperleptinemia was associated with early pregnancy loss. Estimation of the serum level of leptin hormone could be used in cases of early pregnancy loss as a predictor of pregnancy continuation.
\end{abstract}

Keywords: Serum leptin, hyperleptinemia, early pregnancy loss, pregnancy outcome.

Early pregnancy loss is a growing problem all over the world. It occurs in both natural and in-vitro fertilization mediated pregnancies and is one of the most difficult areas in reproductive medicine because the etiology is often unknown. Early pregnancy loss is a heterogenous condition that has many possible causes including genetic, hormonal, metabolic, uterine, anatomical, infectious, environmental, occupational and personal habits, thrombophilia, or immune disorders ${ }^{1,2}$ Leptin is one of the metabolic hormones that is identified as an adipocyte derived protein to modulate satiety and energy homeostasis. It is a 167- aminoacid polypeptide hormone, secreted mainly by adipocyte ${ }^{3}$. Leptin can be produced by human ovarian follicles, both in granulosa and cumulus cell. ${ }^{4}$ It was seen that preovulatory follicles express leptin gene (ob gene) at the level of mRNA and gene. Thus, leptin resistance and/or hyperleptinemia leads to altered follicle functions. ${ }^{5}$ Leptin role in pregnancy was suggested as it is synthesized within the fetoplacental unit and is implicated in various reproductive functions such as the regulation of ovarian function, oocyte maturation, embryo development and implantation ${ }^{6,7}$. Dysregulation of leptin metabolism and/or function may be implicated in pathogenesis of various disorder during pregnancy such as recurrent miscarriages, polycystic ovary syndrome,

Received: $18^{\text {th }}$ February 2021, Peer review completed: $24^{\text {th }}$ March 2021, Accepted: $1^{\text {st }}$ May 2021.

Maddeshiya S, Jain S, Singh S. Role of serum leptin in prediction of pregnancy outcome in women with early pregnancy loss. The New Indian Journal of OBGYN. 2022; 8(2): 304 - 7. 
The New Indian Journal of OBGYN. 2021 (January-June);8(2)

gestational diabetes mellitus, pre-eclampsia and Intrauterine growth restriction. ${ }^{8,9}$

Aims and objectives

- To determine the levels of serum leptin in women with history of previous early pregnancy loss (cases) and previous normal pregnancies (control).

- To compare the levels of serum leptin in women with history of early pregnancy loss and previous normal pregnancies.

- To observe the association between levels of serum leptin and pregnancy outcome.

\section{Materials and methods}

This case control study was carried out on total of 77 pregnant women in first trimester attending outpatient department and indoor cases in Swaroop Rani Nehru hospital and Kamla Nehru Memorial hospital, Prayagraj over a period of twelve months from September 2018 to August 2019. Patients were divided in two groups: group $I(n=52)$ included women with history of previous abortion and group II $(n=25)$ included women with history of no previous abortions.

Inclusion criteria -

Criteria for selection of cases: All pregnant women with singleton pregnancy between 5 to 12 weeks of gestation with history of one or more miscarriage during natural or IVFmediated pregnancy.

Criteria for selection of control: Women with previous normal pregnancy with no history of abortion.

Exclusion criteria -

Women with history of ectopic or molar pregnancy, chronic disease, any relevant hormonal treatment during or shortly before the current pregnancy, previous cervical cerclage and genitourinary infection.

Procedure: For serum leptin level three millilitres of fasting venous blood sample was collected from patients in both groups under aseptic precautions by venepuncture, then put it in a clear plain test tube, after centrifugation, the separated serum was stored at - 20 degree centigrade until use. $1^{\text {st }}$ sample was taken at 5-8 weeks of gestation and second sample at 9-12 weeks of gestation. Serum level of leptin hormone was measured using enzyme linked immunosorbent assay (ELISA) technique. The mean absorbance for each standard, control and samples were calculated. The serum leptin level of the controls and samples was determined from the standard curve by matching their mean absorbance readings with the corresponding human leptin concentrations. Follow up of all patients was done up to 20 weeks to know the pregnancy outcome and documentation of abortion was done by ultrasound and histological examination.

Statistical analysis: The unpaired ' $\mathrm{t}$ ' test or chi-square test was carried out for continuous and categorical variables respectively and descriptive statistics were given as the mean SD. For all statistical analysis $\mathrm{p}<0.05$ was considered as significant.

\section{Results}

Out of total 77 pregnant women, $67.53 \%(52 / 77)$ had history of previous abortion and $32.46 \%$ (25/77) had no history of previous abortion at time of study (table 1).

\section{Table 1: Distribution of cases}

\begin{tabular}{llll}
\hline Groups & Patients & Number & Percentage \\
\hline I & Pregnant with h/o abortion & 52 & $67.53 \%$ \\
II & Pregnant with no h/o abortion & 25 & $32.46 \%$ \\
\hline & Total & 77 & $100 \%$ \\
\hline
\end{tabular}

Out of total patients $32.46 \%$ (25/77) women had no previous miscarriage, $10.28 \% \quad(8 / 77)$ women had 1 miscarriage, $24.675(19 / 77)$ had 2 miscarriage, 19.48\% $(15 / 77)$ cases had 3 miscarriage and $12.98 \%$ (10/77) had more than 3 miscarriage (table 2).

Table 2: Obstetric history

\begin{tabular}{lll}
\hline No. of Miscarriage & Number & Percentage \\
\hline 0 & 25 & $32.46 \%$ \\
1 & 8 & $10.28 \%$ \\
2 & 19 & $24.67 \%$ \\
3 & 15 & $19.48 \%$ \\
$>3$ & 10 & $12.98 \%$ \\
\hline Total & 77 & $100 \%$ \\
\hline
\end{tabular}

Among 52 cases the serum leptin level in $1^{\text {st }}$ sample (5-8 weeks) ranged between $(10.87-36.97 \mathrm{ng} / \mathrm{ml})$ with a mean of $17.918 \pm 6.154 \mathrm{ng} / \mathrm{ml}$; and in subsequent $2^{\text {nd }}$ sample at 9-12 weeks the mean serum leptin level was found to be $25.808 \pm$ $9.393 \mathrm{ng} / \mathrm{ml}$; range (18.22- 51.11 ng/ml) (table 3).

\begin{tabular}{llll} 
Table 3: Serum leptin level in group $\mathbf{I}$ & & \\
\hline $\begin{array}{l}\text { Serum leptin } \\
\text { (ng/ml) }\end{array}$ & $\begin{array}{l}\text { Range } \\
\text { (min- } \mathbf{m a x})\end{array}$ & Mean \pm SD & $\begin{array}{l}\text { P } \\
\text { value }\end{array}$ \\
\hline At $5-8^{\text {th }}$ week & $10.87-36.97$ & $19.477 \pm 7.501$ & 0.0067 \\
At $9-12^{\text {th }}$ week & $18.22-51.11$ & $24.183 \pm 9.705$ & \\
\hline
\end{tabular}

Among control group, the mean serum leptin level in $1^{\text {st }}$ sample (5-8 weeks) was $12.75 \pm 2.147$; range $(8.76-15.86$ $\mathrm{ng} / \mathrm{ml}$ ) and in subsequent $2^{\text {nd }}$ sample at $9-12$ weeks the mean serum leptin level was $17.627 \pm 6.404 \mathrm{ng} / \mathrm{ml}$; range (11.95 - $39.54 \mathrm{ng} / \mathrm{ml}$ ) (table 4).

\begin{tabular}{llll}
\multicolumn{2}{l}{ Table 4: Serum leptin level in group II } \\
\hline $\begin{array}{l}\text { Serum leptin } \\
\text { (ng/ml) }\end{array}$ & $\begin{array}{l}\text { Range } \\
\text { (min- max) }\end{array}$ & Mean \pm SD & $\begin{array}{l}\text { P } \\
\text { value }\end{array}$ \\
\hline At $5-8^{\text {th }}$ weeks & $8.76-15.86$ & $12.75 \pm 2.147$ & 0.0007 \\
At $9-12^{\text {th }}$ weeks & $11.95-39.54$ & $17.627 \pm 6.404$ & \\
\hline
\end{tabular}

The mean serum leptin levels in pregnant women who aborted during study were $21.652 \pm 7.716 \mathrm{ng} / \mathrm{ml}$ at $5-8$ weeks and at 9-12 weeks it was $31.472 \pm 8.56 \mathrm{ng} / \mathrm{ml}$. Serum leptin hormone levels was high $(\mathrm{p}<0.0001)$ in cases who aborted during the study (table 5). 
The New Indian Journal of OBGYN. 2021 (January-June);8(2)

\begin{tabular}{|c|c|c|}
\hline $\begin{array}{c}\text { Aborted group } \\
(\mathrm{n}=\mathbf{3 6})\end{array}$ & $\begin{array}{l}\text { Range (min- max) } \\
(\mathrm{ng} / \mathrm{ml})\end{array}$ & $\begin{array}{l}\text { Mean } \pm \text { SD } \\
(\mathrm{ng} / \mathrm{ml})\end{array}$ \\
\hline At 5- $8^{\text {th }}$ weeks & $11.95-36.97$ & $21.652 \pm 7.716$ \\
\hline At $9-12^{\text {th }}$ weeks & $15.01-44.6$ & $31.472 \pm 8.56$ \\
\hline P-value & & $<0.0001$ \\
\hline
\end{tabular}

\section{Discussion}

In present study, majority of cases in both groups were of 25-29 years of age. The overall mean age of group I was $30.13 \pm 4.265$ years while of group II was $28.92 \pm 4.137$ years. The difference between the two group was statistically insignificant $(\mathrm{p}=0.243)$. This was in accordance to this study of Dorf et al $(2016)^{10}$, Alhour et al (2015) ${ }^{11}$ and Baban et al $(2010)^{12}$.

The mean miscarriage rate in group I was $2.519 \pm 0.970$. In present study, majority of pregnant women (44/52) with previous miscarriage had higher serum leptin levels (14.0 $\mathrm{ng} / \mathrm{ml}$ ). Their absolute mean serum leptin was $19.554 \pm 7.50$ $\mathrm{ng} / \mathrm{ml}$ in $1^{\text {st }}$ sample at 5-8 weeks. In subsequent $2^{\text {nd }}$ sample at 9-12 weeks the mean serum leptin was found to be $27.33 \pm 9.705 \mathrm{ng} / \mathrm{ml}$. In accordance with present study, Dorf et al (2016) found mean serum leptin $(\mathrm{ng} / \mathrm{ml})$ levels as $30.559 \pm 10.672$ and $29.733 \pm 9.133$ in $1^{\text {st }}$ and $2^{\text {nd }}$ sample respectively among cases ${ }^{10}$. Baban et al (2010) also found higher serum leptin level in women with recurrent pregnancy loss (mean $21.03 \pm 6.35 \mathrm{ng} / \mathrm{ml}$ ) as compared to control (mean $8.54 \pm 1.87 \mathrm{ng} / \mathrm{ml})^{12}$. Zarei et al (2010) also found higher serum leptin level in women with immunological recurrent abortion (mean 23.71 $\pm 3.2 \mathrm{ng} / \mathrm{ml}$ ) ${ }^{13}$. Laird et al (2001) found mean leptin levels as $18.1 \pm 2.93 \mathrm{ng} / \mathrm{ml}$ and $20.3 \pm 3.6 \mathrm{ng} / \mathrm{ml}$ in $1^{\text {st }}$ and $2^{\text {nd }}$ sample respectively in patients with recurrent pregnancy $\operatorname{loss}^{14}$. Nanda et al (2012) observed increased maternal serum leptin concentration at 11-13 weeks gestation in pathological pregnancies that may subsequently lead to abortion ${ }^{15}$. Žaneta et al (2004) suggested that elevation of leptin level could be an indicator for the cessation of pregnancy naturally either at term or due to pathology at any time during gestation ${ }^{16}$.

In pregnant women with no history of abortion serum leptin level was in the range of $8.76-15.86 \mathrm{ng} / \mathrm{ml}$ at $1^{\text {st }}$ sample $\left(5-8^{\text {th }}\right.$ weeks $)$ with mean serum leptin level $12.75 \pm 2.147 \mathrm{ng} / \mathrm{ml}$ and at $2^{\text {nd }}$ sample $\left(9-12^{\text {th }}\right.$ weeks), range was $11.95-39.54 \mathrm{ng} / \mathrm{ml}$ with mean serum leptin level $17.62 \pm 6.53 \mathrm{ng} / \mathrm{ml}$. Similar was the observation of Laird et al (2001) with maternal serum total leptin levels elevated during pregnancy with alterations particularly during the second and third trimesters ${ }^{14}$.
In the present study, 32 patients $(61.53 \%)$ in group I and four patients $(16.0 \%)$ in group II aborted during study. Twenty patients $(40.38 \%)$ in group I completed $20^{\text {th }}$ weeks of gestation compared to twenty-one patients (84\%) in group II. In aborted group, 44 cases $(84.6 \%)$ with previous history of abortion had higher serum leptin levels $(>14.0 \mathrm{ng} / \mathrm{ml})$ while 19 patients $(76 \%)$ with no history of abortion had higher serum leptin. Six patients $(11.53 \%)$ in group I and three patients $(12 \%)$ in group II had higher serum leptin level in both $1^{\text {st }}$ and $2^{\text {nd }}$ sample and completed 20 weeks. On the other hand, the aborted cases that showed higher level of leptin in both first and second sample were 8 (15.38\%) and 3 $(12 \%)$ in the group I and group II respectively. In accordance with present study Dorf et al (2016) found twenty-nine patients $(82.8 \%)$ in the control group completed 20th weeks of gestation compared to 13 patients $(37.1 \%)$ in the study group $^{10}$.

\section{Conclusion}

In the present study the mean serum leptin hormone level was higher in cases with history of previous early pregnancy loss. Higher level was also seen in cases who aborted during the study. Therefore, it was concluded that hyperleptinemia could lead to pregnancy loss. It is recommended that leptin hormone evaluation should be done within 12 weeks of gestation as most pregnancy losses occurred during the first trimester specially in cases of abortions where no specific medical cause for pregnancy loss is found. Leptin hormone could be used in cases of early pregnancy loss as a predictor of pregnancy continuation. However, our study was limited by a small study population and large scale studies are needed to confirm these results.

\section{Conflict of interest: None. Disclaimer: Nil.}

\section{References}

1. Ford HB, Schust DJ. Recurrent Pregnancy Loss: Etiology, Diagnosis, and Therapy. Rev Obstet Gynecol. 2009; 2(2): 76-83.

2. Pluchino N, Drakopoulos P, Wenger JM, Petignat P, Streuli I, Genazzani AR. Hormonal causes of recurrent pregnancy loss. Hormones. 2014; 13(3): 314-22.

3. Wolf G, Ziyadeh FN. Leptin and renal fibrosis. Contrib Nephrol. 2006;151:175-83

4. Joo JK, Joo BS, Kim SC, Choi J, Park S, Lee K. Role of leptin in improvement of oocyte quality by regulation of ovarian angiogenesis. Animal Reproduction Science. 2010; 119: 329-34. 
The New Indian Journal of OBGYN. 2021 (January-June);8(2)

5. Karlsson C, Lindell K, Svensson E, et al. Expression of functional leptin receptors in the human ovary. J Clin Endocrinol Metab. 1997; 82: 4144-48.

6. Herrid M, Palanisamy SK, Ciller UA, et al. An updated view of leptin on implantation and pregnancy: a review. Physiol Res. 2014; 63: 543-57.

7. Pérez-Pérez A, Sánchez-Jiménez F, Maymó J, et al. Role of leptin in female reproduction. Clin Chem Lab Med. 2015; 53: 15-28.

8. Grattan D, Ladyman S, Augustine R. Hormonal induction of leptin resistance during pregnancy. Physiology and Behavior. 2007; (4): 366-74.

9. Perez- Perez A, Toro A, Vilarino- Gracia T, Maymo J, Guadix P, Duenas JL, et al. Leptin action in normal and pathological pregnancies. J cell and mol med. 2018 Feb; 22(2): 716-27.

10. Dorf AAE, Ossman AME, Halwagy AESE, Borg HM, Abd-Elbar ES. Use of Serum Leptin and Insulin Hormones Levels as Predictor of pregnancy outcome in pregnant women with history of recurrent early pregnancy loss. Middle East Fertility Society Journal. 2016 Mar; 21(1): 36-40

11. Alhour, Nabil A. Serum Leptin Level in Women with Recurrent Pregnancy Loss in Mid-Zone Governorate, Gaza strip. The Islamic University of Gaza. 2015.

12. Baban RS, Ali NM, Al-Moayed HA. Serum Leptin and Insulin Hormone Level in Recurrent Pregnancy Loss. Oman Med J. 2010 Jul; 25(3): 203-7.
13. Zarei S, Soltanghoree H, Mohammadzadeh A, Arefi S, Zarnani A H, Idali F, et al. Serum Leptin Levels in women with Immunological Recurrent Abortion. J Reprod Infertil. 2010 Apr-Jun; 11(1): 47-52.

14. Laird SM, Quinton ND, Anstie B, Li TC, Blakemore A. Leptin and leptin - binding activity in women with recurrent miscarriage: correlation with pregnancy outcome. Hum Report. 2001; 16(9): 2008-13.

15. Nanda S, Akolekar R, Acosta IC, Nicolaides WD. Maternal Serum Leptin at 11-13 weeks Gestation in Normal and Pathological Pregnancies. J Metabolic Synd. 2012;1: 4

16. Žaneta K, Gražina D, Zita K. Serum leptin levels in pregnant women and umbilical cord: relationship to mother and neonate anthropometry. Acta Medica Lituania. 2004; 11(3): 26-30.

\footnotetext{
Sheela Maddeshiya ${ }^{1}$, Shakti Jain ${ }^{2}$, Shalini Singh ${ }^{3}$

${ }^{1}$ Senior Resident, Department of Obs and Gynae, MLN Medical College, Prayagraj, Uttar Pradesh, India;

${ }^{2}$ Associate Professor, Department of Obs and Gynae, MLN Medical College, Prayagraj, Uttar Pradesh, India; ${ }^{3}$ Associate Professor, Department of Obs and Gynae, MLN Medical College, Prayagraj, Uttar Pradesh, India.
} 